ТЕНДЕНЦІЇ МОДЕРНІЗАЦІЇ НАВЧАЛЬНОГО КОНТЕНТУ ФАХОВОЇ ПІДГОТОВКИ МАЙБУТНІХ СОЦІАЛЬНИХ ПЕДАГОГІВ ДО РОБОТИ 3 ДІТЬМИ У ЗАГАЛЬНООСВІТНІЙ ШКОЛІ 3 УРАХУВАННЯМ СУЧАСНИХ ОСВІТНІХ ЗАПИТІВ

\title{
TRENDS OF MODERNIZATION OF THE FUTURE SOCIAL PEDAGOGES' EDUCATIONAL CONTENT OF PROFESSIONAL PREPARATION TO WORK WITH CHILDREN IN A GENERAL SCHOOL TAKING INTO ACCOUNT THE MODERN EDUCATIONAL REQUESTS
}

УДК 378.013.42.011.3-051

DOI https://doi.org/10.32843/2663-

6085.2019.12-1.10

\section{Великжаніна Д.В.,}

аспірант кафедри педагогіки

і педагогічної майстерності

Мелітопольського державного

педагогічного університету

імені Богдана Хмельницького

\begin{abstract}
у статті розглянуто сучасні освітні орієнтири, визначено актуальність реалізаціі компетентнісного підходу до навчання та виховання молодого покоління. Здійснено спробу обгрунтування необхідності соціально-педагогічної роботи у закладі середньої освіти з підлітками в напрямі фоормвання їхньої життєвої компетентності. Окреслено тенденції модернізації навчального контенту профресійної підготовки майбутніх соціальних педагогів до роботи у закладах середньої освіти з урахуванням сучасних освітніх запитів. Здійснено аналіз робочих програм навчальних дисциплін циклу професіійної підготовки майбутніх соціальних педагогів. Запропоновано тематику оновлення змісту теоретичної і практичної фахової підготовки майбутніх соціальних педагогів до роботи у школі щодо формування життєвої компетентності підлітків. Ключові слова: життєва компетентність, майбутній соціальний педагог, підліток, фрахова підготовка соціальних педагогів, профресійна компетентність, навчальний контент.
\end{abstract}

B cmamье рассмотрены современные образовательные ориентиры, определена актуальность реализации компетентностного подхода к обучению и воспитанию подрастающего поколения. Предпринята попытка обоснования необходимости социально-педагогической работы в учреждении среднего образования с подростками в направлении фрормирования их жизненной компетентности. Определены тенденции модернизации учебного контента профессиональной подготовки будущих социальных педагогов к работе в учреждениях сред- него образования с учётом современных образовательных запросов. Проанализированы рабочие программы учебных дисциплин цикла профьессиональной подготовки будущих социальных педагогов. Предложена тематика обновления содержания теоретической и практической профессиональной подготовки будущих социальных педагогов к работе в школе по формированию жизненной компетентности подростков. Ключевые слова: жизненная компетентность, будущий социальный педагог, подросток, профессиональная подготовка социальных педагогов, профеессиональная компетентность, учебный контент.

The article deals with modern educational guidelines, the relevance of the implementation of a competent approach to the education and upbringing of the younger generation is determined. There was an attempt to substantiate the need for social-pedagogical work in an institution of secondary education with adolescents in the direction of forming their vital competencies. The trends of modernization of the future social pedagogues' educational content of professional training for work in secondary education institutions taking into account modern educational demands are outlined. The analysis of educational disciplines working programs of the future social pedagogues' professional training cycle is carried out. It is proposed to update the future social pedagogues' theoretical and practical training content to work in school in relation to the adolescents' formation of life competence.

Key words: life competence, future social pedagogues, adolescent, social pedagogues' training content, professional competence, educational content.
Постановка проблеми у загальному вигляді. Сучасна соціально-педагогічна освіта не є статичною. Вона перебуває у безперервному процесі оптимізації, транссормації, оновлення й інноваційного пошуку, адаптуючись до нагальних суспільно-економічних, інформаційно-технологічних та освітніх потреб українського соціуму. Професійна компетентність соціального педагога нині має гарантувати результативну соціально-педагогічну діяльність, забезпечувати продуктивну комунікацію та взаємодію соціального педагога як фрахівця з усіма учасниками процесу особистісного, соціального й життєвого становлення молодого покоління, а також підпорядковується низці закономірних та довгоочікуваних змін у системі освіті. Такими змінами є орієнтація освітніх запи- тів на практичний складник процесу навчання, на провадження компетентнісного підходу в освіті і набуття дітьми справді затребуваних навичок та умінь, на реалізацію у сучасній школі ідей гуманізму, дитиноцентризму, толерантності, інноваційності, креативності.

Впровадження нових освітніх орієнтирів покликана здійснити Нова українська школа, мета якої полягає в створенні комсоортних умов для набуття молодим поколінням ключових компетентностей для життя та успішної самореалізації особистості в суспільстві, для всебічного розвитку та соціалізації кожної дитини, для виховання загальнолюдських цінностей учнів та фрормування в них готовності до свідомого життєвого вибору, трудової діяльності і громадянської активності [5]. Одне 
3 центральних місць у Концепції Нової української школи посідає змістовна лінія щодо фрормування життєвої компетентності учнів, яка передбачає оволодіння ними новими й ефективними способами мислення та діяльності, набуття практичних умінь самостійно вирішувати життєві завдання і проблеми, визначати життєві цілі та засоби їх досягнення, спрямовувати внутрішні ресурси на самопізнання, саморозвиток та самовдосконалення, а також готовність особистості до успішної самореалізації та життєтворчості.

Особливого значення життєва компетентність набуває у підлітковому віці, який характеризується активним розвитком соціального пізнання особистості - здатності до розуміння соціальних стосунків, що зумовлює прийняття підлітком соціальних ролей. Життєвий простір підлітка сповнений можливостями і водночас невизначеністю: підліток частково належить до групи дітей, а частково - до групи дорослих. Відсутність необхідних для прийняття рішень когнітивних структур зумовлює невпевненість у поведінці підлітків і окреслює можливості індивідуальних варіацій поведінкових сценаріїв. Крім того, дітям підліткового віку властиві прагнення до відстоювання своєї дорослості, самостійності, незалежності, а також загострення потреби у самопізнанні, саморозумінні і самоствердженні. Вони перебувають у постійному пошуку свого місця у навколишньому світі, індивідуальної моделі поведінки та життєвих авторитетів, потребують соціальної ідентифікації та прийняття. Задоволення підлітком таких прагнень і потреб формує способи його поведінки, що дають йому змогу і надалі справлятися із життєвими труднощами [21, с. 21].

Тому підлітки потребують специорічного соціально-педагогічного супроводу на шляху свого особистісного й соціального розвитку, партнерської підтримки та демократичного наставництва в процесі набуття життєвої компетентності.

За таких умов сучасний соціальний педагог має бути готовий співпрацювати 3 підлітками щодо їхньої успішної соціалізації, життєвого самовизначення та цілепокладання, набуття життєвого знання й досвіду, при цьому вдало поєднувати розкриття особистісного потенціалу підлітків із ресурсами нової школи задля різнобічного розвитку кожного учня.

Так, закономірно виникає необхідність модернізації професійної підготовки соціальних педагогів 3 акцентом на фоормвання готовності й здатності до результативної практичної діяльності в контексті всебічного розвитку й фрормування ключових компетентностей для життя підлітків та освітніх рефрормувань щодо реалізації компетентнісного підходу у навчанні і вихованні молодого покоління в цілому.

Аналіз останніх досліджень і публікацій. Дослідженню теоретико-методологічних засад професійної підготовки соціальних педагогів присвячені наукові праці таких вітчизняних науковців, як: О. Безпалько, В. Багрій, В. Бочарова, Р. Вайнола, Т. Веретенко, В. Галузинський, Н. Гордієнко, О. Гура, М. Гур'янова, І. Доброскок, М. Євтух, І. Звєрєва, А. Капська, О. Карпенко, Л. Коваль, І. Козубовська, Г. Лактіонова, Л. Міщик, В. Поліщук, Л. Романовська, Н. Сейко, С. Харченко та ін.

Проблеми практичної реалізації різних векторів соціально-педагогічної діяльності у своїх дослідженнях розглядають 3. Бондаренко, М. Волошенко, І. Галатир, Н. Заверіко, С. Марченко, Л. Мітіна, О. Остапчук, О. Платонова, М. Приходько, О. Тютюнник, 3. Фалинська, О. Філь, М. Ярошко та ін.

Виділення не вирішених раніше частин загальної проблеми. Водночас, спираючись на наявні наукові напрацювання з питань підготовки майбутніх соціальних педагогів до професійної діяльності й проблем провадження у сучасній школі такої актуальної нині компетенісно спрямованої освіти та розвитку у дітей ключових компетентностей для життя, потребують висвітлення, на нашу думку, особливості фрахової підготовки майбутніх соціальних педагогів у напрямі фрормування життєвої компетентності саме підлітків як специфічно вразливої до суспільних впливів категорії дітей.

Мета статті. Метою статті є окреслення актуальних тенденцій модернізації навчального контенту фрахової підготовки майбутніх соціальних педагогів до роботи 3 дітьми у загальноосвітній школі в сучасних умовах; аналіз робочих програм навчальних дисциплін циклу професійної підготовки майбутніх соціальних педагогів і пропозиції їх оновлення щодо оптимізації процесу фрахової підготовки майбутніх соціальних педагогів до роботи у школі в напрямі фрормування життєвої компетентності молодого покоління, зокрема підлітків.

Виклад основного матеріалу. Визначення сучасних тенденцій модернізації фрахової підготовки майбутніх соціальних педагогів до роботи у загальноосвітній школі, зокрема навчального контенту, потребує аналізу актуальної законодавчої бази сорери освіти та окреслення нагальних потреб у розвитку особистості дитини у школі в умовах сьогодення.

Актуальний нині компетентнісний підхід в освіті орієнтує зусилля освітян на навчання й виховання дітей та молоді, які дадуть змогу здобувачам освіти оволодіти необхідними нині й корисними життєвими уміннями, знаннями з практичною основою і засобами їх творчої реалізації.

Компетентнісно спрямована освіта передбачає оволодіння учнями уміннями розв'язувати проблеми різних видів складності у різних сорерах життя людини на основі наявних знань. Основним освітнім результатом за умов впровадження ком- 
петентнісного підходу має стати не система знань, умінь і навичок, а набір ключових компетентностей в інтелектуальній, комунікативній, інфрормаційній, соціальній та інших сорерах [9, с. 271].

Необхідність реалізації компетентнісного підходу у сучасній освіті закріплено Законом «Про освіту», де результатами навчання зазначаються компетентності, а вектором освітнього розвитку перехід від знаннєвої школи до школи компетентностей, які потрібні людині в XXI сторіччі [11] Відповідно до Закону «Про освіту» метою повної загальної середньої освіти є всебічний розвиток, виховання і соціалізація особистості, яка здатна до життя в суспільстві та цивілізованої взаємодії 3 природою, має прагнення до самовдосконалення і навчання впродовж життя, готова до свідомого життєвого вибору та самореалізації, відповідальності, трудової діяльності та громадянської активності. Досягнення цієї мети забезпечується шляхом фрормування ключових компетентностей, необхідних кожній сучасній людині для успішної життєдіяльності [11].

Так, фрормування життєвої компетентності учнів стає одним 3 ключових завдань сучасної освіти. Соціум вимагає від особистості самостійності, відповідальності за рішення й вчинки, соціальної активності, конкурентоспроможності, освіченості, ефрективності, цілеспрямованості. А особистість, своєю чергою, прагне успішної самореалізації, саморозвитку, розкриття творчого потенціалу.

Простором орормування життєвої компетентності дитини нині має виступати школа. У Концепції Нової української школи охарактеризовано сучасне освітнє середовище, яке має бути створене на базі закладу середньої освіти. У Новій школі зміні підлягають фрізичне просторово-предметне оточення, програми та засоби навчання. Це сприятиме розвитку дитини і мотивації ії до навчання, фрормуванню технологічних компетенцій через запровадження ІКТ у всіх видах освітньої діяльності учнів, фрормуванню навичок наукової діяльності і винахідництва, багатої варіативності організації освітньої діяльності учнів, фрормуванню в учнів потрібних для успішної самореалізації в суспільстві компетентностей, компетентностей для життя, співпраці всіх учасників освітнього процесу на засадах партнерства, орієнтації на потреби учнів в освітньому процесі та індивідуальний підхід [5].

Сучасна школа виступає ресурсним осередком розвитку молодого покоління і використання оновлених ресурсів школи у становленні особистості дитини, у її всебічному розвитку, набутті соціального досвіду та життєвої компетентності в цілому, що має стати фрундаментальною позицією соціально-педагогічної роботи з дітьми.

Також згідно з Концепцією Нової української школи, рефрормування сучасної освіти є поступо- вим. I нині впровадженню підлягає «Друга фраза» (2019-2022 рр.) рефрормування освіти, за якою має бути здійснена розробка та затвердження стандартів базової середньої освіти на компетентнісній основі. Базова середня освіта у Новій українській школі поділятиметься на два цикли: перший - адаптаційний (5-6 класи), другий базове предметне навчання (7-9 класи). Відомо, що учнями середньої школи (5-9 класи) є підлітки, які потребують особливої уваги з боку батьків і педагогів з питань індивідуального й соціального розвитку, навчання, виховання життєвих цінностей і самореалізації. Сукупність фракторів реформування освіти та вікових особливостей підлітків зумовлює потребу профресійної готовності педагогів до роботи з учнями підліткового віку в напрямі реалізації компетентнісного підходу у навчанні і вихованні на засадах довірливих та демократичних відносин, взаємоповаги, діалогічного спілкування і паритетних стосунків.

Важливим аспектом у вирішенні сучасних освітніх завдань щодо всебічного розвитку особистості учня та фрормування у нього ключових компетентностей для успішної життєдіяльності є компетентність педагога як особистості й фрахівця. Компетентний педагог, який демонструє свою готовність до постійного особистісного й професійного самовдосконалення, використання інновацій у практичній професійній діяльності, побудови партнерських відносин з усіма учасниками освітнього процесу, вияву соціальної активності, педагогічної ініціативності, може бути для учнів прикладом для наслідування, авторитетним помічником та тьютором на шляху їхнього особистісного та життєвого розвитку. Тому логічною і зрозумілою, затребуваною й надважливою нині стає й професійна підготовка фрахівців, особливо педагогів, на засадах компетентнісного підходу у навчанні. Адже компетентність продукує компетентність і здобуття професійної освіти за умов акценту на практичність фрахового знання, розвитку критичного мислення, вияву творчості, готовності до інновацій, інтеграція практики у безперервний освітній процес студентів дасть змогу сприяти успішній реалізації компетентнісного підходу до освіти в середній школі під час їхньої подальшої професійної діяльності.

Спираючись на вищевказане, такими тенденціями модернізації навчального контенту фрахової підготовки майбутніх соціальних педагогів можна визначити: компетентнісний підхід до професійної підготовки студентів під час навчання у закладі вищої освіти; концентрація уваги майбутніх соціальних педагогів на використанні у практичній соціально-педагогічній роботі ресурсів школи як комфрортного простору для реалізації компетентнісних орієнтирів в освіті та розвитку життєвої компетентності учнів в умовах сучасності; орієнтація майбутніх соціальних педагогів на роботу 3 
підлітками в напрямі фрормування їхньої життєвої компетентності як специфрічної категорії учнів, що потребують зосередженої уваги з боку дорослих та фрахівців щодо власного особистісного та соціального розвитку з огляду на особливості віку.

Для оптимальної реалізації визначених тенденцій модернізації фахової підготовки майбутніх соціальних педагогів до роботи 3 підлітками в напрямі фрормування їхньої життєвої компетентності в умовах закладу середньої освіти було проаналізовано робочі навчальні програми дисциплін циклу профресійної підготовки студентів напряму підготовки 6.010106 Соціальна педагогіка та спеціальності 231 Соціальна робота (в тому числі і студентів, які навчаються за освітньо-профресійною програмою «Соціальна педагогіка»): «Соціальнопедагогічна робота в закладах освіти», «Технології соціально-педагогічної роботи», «Соціалізація особистості». Аналіз робочих навчальних програм дає змогу зробити висновок про необхідність їх доповнення додатковими змістовними модулями та тематикою для вивчення, які б сприяли розширенню й поглибленню професійної підготовки майбутніх бакалаврів соціальної педагогіки саме в контексті фрормування життєвої компетентності молодого покоління в умовах загальноосвітнього навчального закладу.

Так, аналіз робочих навчальних програм 3 навчальної дисципліни «Соціально-педагогічна робота в закладах освіти» демонструє їх змістове наповнення за такою тематикою: сутність та специфріка роботи соціального педагога у загальноосвітніх навчальних закладах різних типів; школа як соціально-педагогічна система, профресійна діяльність соціального педагога (функціональне поле, документація, напрями діяльності), принципи і методи соціально-педагогічної роботи в школі; законодавча база діяльності соціального педагога в закладах середньої освіти; робота соціального педагога в закладах освіти із сім'єю, важковиховуваними дітьми та дітьми 3 особливими освітніми потребами; соціально-педагогічна робота 3 підлітками, схильними до правопорушень, та дітьми з неблагополучних сімей; соціально-педагогічна робота щодо профресійної орієнтації учнів та їх підготовки до сімейного життя; соціально-педагогічна діагностика та консультування, профрілактична та корекційно-розвивальна діяльність [12; 15; 16; 19]. Доцільним було б доповнення змісту такої навчальної дисципліни темами для вивчення, які мають зорієнтувати майбутніх соціальних педагогів на роботу з підлітками у школі в напрямі фрормування їхньої життєвої компетентності та надати відповідні знання з цієї проблеми. Пропонується така тематика в межах вивчення цієї дисципліни: ресурси закладу середньої освіти щодо фрормування життєвої компетентності учнів; соціальнопедагогічна робота щодо організації продуктивних комунікацій та взаємодії учасників освітнього процесу; соціально-педагогічна робота з підлітками у школі щодо: налагодження 3 ними партнерських відносин, вирішення конфрліктних ситуацій у підлітковому середовищі, протидія булінгу, залучення їх до соціально корисної та волонтерської діяльності, успішної соціалізації й набуття підлітками ключових життєвих компетенцій у процесі навчання та виховання, ознайомлення зі стратегіями планування та досягнення цілей у різних сорерах життєдіяльності, стратегіями досягнення життєвого успіху в цілому, соціально-педагогічної підтримки та супроводу на шляху особистісного становлення та саморозвитку; соціально-педагогічний інструментарій фрормування життєвої компетентності учнів в умовах загальноосвітнього закладу (технології, фрорми, методи соціально-педагогічної діяльності).

Аналіз робочих навчальних програм 3 дисципліни «Технології соціально-педагогічної роботи» свідчить про таку соціально-педагогічну проблематику, яка пропонується студентам для вивчення в межах цієї фрахової дисципліни: технологізація соціально-педагогічної діяльності (технологія індивідуальної та групової соціально-педагогічної роботи); загальні технології соціально-педагогічної діяльності (соціальна діагностика, терапія, корекція, консультування та профрілактика); спеціальні технології соціально-педагогічної діяльності (соціальний захист населення, соціальна опіка та піклування, соціальний супровід, патронаж та допомога); технології соціально-педагогічної діяльності з різними групами клієнтів (робота з дітьми вулиці, дітьми і молоддю, що потребують особливої допомоги, робота в громаді, з окремими типами сімей, волонтерська робота); технології соціально-педагогічної роботи з дітьми групи ризику [13]; технології соціально-педагогічної роботи 3 молоддю (технологія роботи з дитячими, юнацькими та молодіжними громадськими організаціями, сприяння працевлаштуванню і залученню до волонтерської роботи), з обдарованими дітьми та їхніми батьками; технологія консультативної соціальнопедагогічної допомоги, психолого-терапевтичного консультування по телефону, технологія проведення групової психолого-педагогічної терапії [17]; соціальні інновації та технології соціального прогнозування; форми та методи соціально-педагогічної діяльності; соціально-педагогічна робота в умовах оздоровчого табору; рекламно-інформаційні технології у діяльності соціального педагога; технології соціальної терапії, соціально-педагогічної допомоги і підтримки осіб з обмеженими можливостями; технології соціально-педагогічної роботи з мігрантами та біженцями, в пенітенціарній системі, сільській громаді, у загальноосвітньому навчальному закладі, 3 дезадаптованими підлітками та дітьми 3 девіантною поведінкою, 3 
проблемними сім'ями $[1 ; 13 ; 20]$. Конкретизувати та розширити фрахову підготовку майбутніх соціальних педагогів з проблеми фрормування життєвої компетентності учнів, зокрема підлітків, у процесі реалізації соціально-педагогічних фрункцій у загальноосвітньому навчальному закладі пропонується за рахунок доповнення робочої навчальної програми цієї дисципліни такою тематикою: технології фрормування життєвої компетентності учнів (технологія проективного життєздійснення, інтерактивні педагогічні технології, технологія проектної діяльності, дослідницького навчання, технологія планування життєдіяльності дитячого колективу, технологія педагогічного супроводу розвитку життєвої комптентності) [8]; технологія формування творчої особистості підлітка в умовах загальноосвітнього навчального закладу [3; 22]; технології педагогічної підтримки і супроводу індивідуальної траєкторії розвитку і саморозвитку особистості [7, с. 232]; технологія орормування критичного мислення [5; 7, с. 273; 10]; технології збереження здоров'я учнів [18].

Аналіз робочих навчальних програм 3 дисципліни «Соціалізація особистості» дає змогу зазначити таку тематику для вивчення майбутніми соціальними педагогами: концептуальні засади процесу соціалізації особистості (соціалізація особистості як соціально-педагогічне явище; етапи, механізми, фрази соціалізації; соціальна адаптація, дезадаптація, реадаптація особистості в процесі соціалізації, вплив 3МІ та субкультур на особистість у процесі соціалізації; політична та економічна соціалізація; критичні періоди у розвитку особистості, особливості вікових етапів соціалізації); вплив мікрофракторів, мезофракторів та макрофракторів на соціалізацію особистості (сім'я, група ровесників, освітній заклад, субкультури, соціально-культурне середовище, регіон, етнос, держава як фрактори соціалізації), несприятливі чинники соціалізації $[2 ; 4 ; 6 ; 14]$; соціалізація як процес опанування культурного досвіду (статево-рольова соціалізація особистості; культура, освіта та соціальні групи як інститути соціалізації; духовний розвиток особистості в процесі соціалізації) [2]. Доповнення змісту навчальної дисципліни «Соціалізація особистості» тематикою $з$ проблем соціально-педагогічної роботи в загальноосвітньому навчальному закладі з дітьми щодо сприяння їхньої соціалізації та фрормування життєвої компетентності, на наш погляд, дало би змогу поглибити та закріпити знання і професійні компетентності майбутніх соціальних педагогів 3 питань практичної роботи з дітьми з урахуванням сучасних освітніх запитів, зокрема реалізації компетентнісного підходу в освіті. Актуальними у цьому контексті в межах дисципліни «Соціалізація особистості» можна виділити такі теми для вивчення майбутніми соціальними педагогами: взаємозв'язок процесів соціалізації та набуття життєвої компетентності особистості; вплив соціалізації особистості на вибір життєвих цілей та стратегій їх досягнення, життєвих траєкторій, цінностей та установок; значення соціальних інститутів у фрормуванні життєвої компетентності молодого покоління; загальноосвітня школа як простір соціального та особистісного становлення учня, набуття ним ключових компетентностей для життя; специфріка роботи соціального педагога у школі в напрямі соціалізації учнів та фрормування їхньої життєвої компетентності; проблеми соціалізації підлітків як особливо вразливої вікової категорії та їх орієнтація на позитивне особистісне зростання та саморозвиток, фоорування відповідальної поведінки та самостійності, життєвої компетентності в цілому.

Запропоновані теми, які можуть вивчатись студентами в межах вищевказаних дисциплін, розширять знання майбутніх соціальних педагогів 3 проблем реалізації компетентнісного підходу в освіті, провадження соціально-педагогічної діяльності на засадах гуманізації, демократизації, дитиноцентризму в освіті. Також запропонована для вивчення студентами тематика, на наш погляд, дасть змогу оволодіти майбутнім фрахівцям соціальної сфери професійними компетентностями щодо: продуктивного виконання функцій соціального педагога у школі; особливостей використання ним ресурсів загальноосвітнього закладу в роботі 3 дітьми в напрямі сприяння їхньому особистісному зростанню, успішної соціалізації, побудови життєвих цілей та планів і вибору стратегій їх досягнення; специфріки соціально-педагогічної роботи 3 дітьми підліткового віку, здійснення консультативної, профрілактичної, мотивуючої та розвивальної роботи 3 підлітками; використання у професійній діяльності сучасних педагогічних засобів (інноваційних освітніх технологій, розмаїття соціальних видів діяльності, освітніх веб-ресурсів тощо) задля сприяння формуванню життєвої компетентності учнів, їхнього особистісного і життєвого становлення.

Важливим аспектом фахової підготовки майбутніх соціальних педагогів до реалізації профресійних фрункцій у школі $є$ фрормування практичних умінь і навичок. Тому окреме місце у вивченні студентами фахових дисциплін займають практичні заняття. Доцільним було б доповнення, на нашу думку, практичних занять з дисциплін «Соціальнопедагогічна робота в закладах освіти», «Технології соціально-педагогічної роботи», «Соціалізація особистості» такими практичними завданнями для студентів, які б сприяли розвитку у них практичних умінь і навичок формування ключових життєвих компетентностей учнів у школі, а також розвитку позитивного й зацікавленого ставлення до майбутньої профресії. Такими практичними завданнями можуть бути: створення індивідуальних 
та спільних тематичних презентацій (наприклад, під час вивчення навчальної дисципліни у Google Classroom); складання планів вирішення соціально-педагогічних задач; підготовка, організація та участь у соціально корисних видах діяльності (благодійні акції, волонтерські програми, програми організації змістовного дозвілля підлітків тощо); розробка соціально-педагогічних експресанкет (наприклад, за допомогою онлайн-сервісів Anketolog, Google Forms, Testograf, Typeform, Survey Monkey) для підлітків щодо визначення їхніх особистісних характеристик, ціннісних орієнтацій, інтересів і захоплень, проблем і рівнів конфліктності, планів на найближче майбутнє, поведінкових реакцій у різних життєвих ситуаціях тощо; складання банку форм самопрезентації для підлітків; складання бази корисних веб-ресурсів для дітей підліткового віку щодо мотивації їхнього саморозвитку, самоосвіти, творчого розвитку та розвитку критичного мислення, фрормування здорового способу життя; мозковий штурм та розробка схеми потенціалу загальноосвітньої школи щодо фрормування життєвої компетентності молодого покоління; розробка сценаріїв соціальнопедагогічних заходів для дитячих колективів (тренінгів, ігор, квестів, конкурсів, вікторин тощо), спрямованих на сприяння особистісного розвитку учнів, набуття ними життєво важливих й соціально-практичних умінь; складання карток з проблемними ситуаціями для їх розв'язання під час індивідуальної та групової роботи з підлітками; складання планів зустрічей підлітків з фахівцями у різних професійних сорерах (лікарями, спортсменами, музикантами, освітянами, підприємцями, інженерами, програмістами, громадськими діячами тощо), пізнавальних екскурсій; підготовка, організація та участь у тематичних flash mobs; розробка варіантів дизайну проведення днів виконання учнями різних соціальних ролей.

Так, оновлений навчальний контент орахової підготовки майбутніх соціальних педагогів поєднує вивчення студентами теоретичного знання із паралельною практичною роботою, що сприяє більш ефективному оволодінню студентами фаховою компетентністю та її інтеграції у профресійнопрактичну площину.

Висновки. Таким чином, проблема модернізації навчального контенту професійної підготовки майбутніх соціальних педагогів у напрямі фрормування життєвої компетентності молодого покоління $€$ натепер актуальною, адже їі вирішення спрямоване на реалізацію сучасних освітніх запитів, зокрема впровадження компетентнісного підходу в освіті, створення комфортного та інноваційного освітнього середовища для кожного учня, на всебічний та гармонійний розвиток дітей, їх виховання і соціалізацію, формування життєвої компетентності. Врахування зазначених у статті тен- денцій модернізації фрахової підготовки бакалаврів соціальної педагогіки дасть змогу спрямувати цей процес на досягнення цілей і задач сучасної вищої та загальної середньої освіти, на досягнення позитивних результатів у професійній соціально-педагогічній діяльності з учнями на практиці.

Перспективами подальших наукових розвідок у напрямі профресійної підготовки майбутніх соціальних педагогів щодо формування життєвої компетентності підлітків вважаємо вивчення й обґрунтування оптимальних педагогічних умов для успішної реалізації запропонованих оновлень у навчальному контенті фахової підготовки бакалаврів соціальної педагогіки до практичної роботи 3 підлітками у школі щодо фрормування в них ключових компетентностей для життя.

\section{БІБЛІОГРАФІЧНИЙ СПИСОК:}

1. Бешок Т.В. Технології соціально-педагогічної роботи: робоча програма для студентів спеціальності 6.010106 Соціальна педагогіка. Кременець. 2016. 21 c.

2. Бешок Т.В. Соціалізація особистості: робоча програма для студентів спеціальності 6.010106 Соціальна педагогіка. Кременець, 2016. 13 с.

3. Вайновська М.К. Формування творчої особистості підлітка у навчально-виховному процесі : автореф. дис... канд. пед. наук : спец. 13.00.07. Херсон, 2004. 33 c.

4. Зозуляк-Случик Р.В. Основи соціалізації особистості : навчальний посібник для студентів вищих навчальних закладів. Івано-Франківськ : HAIP, 2015. 218 c.

5. Концептуальні засади реформування середньої школи «Нова українська школа». 2016. 40 с. URL: https://www.kmu.gov.ua/storage/app/media/reforms/ ukrainska-shkola-compressed.pdf.

6. Методичні рекомендації до курсу «Соціалізація особистості» / укладачі: О.Л. Остапчук, С.А. Котловий. Житомир : Вид-во ЖДУ ім. І. Франка, 2017. $48 \mathrm{c}$.

7. Михайліченко М.В., Рудик Я.М. Освітні технології : навчальний посібник. Київ : ЦП «КОМПРИНТ», 2016. 583 c.

8. Нечипоренко В.В. Системний розвиток навчально-реабілітаційного центру як відкритої інноваційної соціально-освітньої інституції : монографрія. Запоріжжя : Видавництво Хортицького національного навчально-реабілітаційного багатопрофільного центру, 2013. 512 с.

9. Паламар С. Компетентнісний підхід як методологічний орієнтир модернізації сучасної освіти. Освітологічний дискурс. Київ, 2018. № 1-2 (20-21). С. 267-278.

10. Пометун О. Як розвивати критичне мислення в учнів (з прикладом уроку). URL: http://nus.org.ua/ articles/krytychne-myslennya-2/.

11. Про освіту : Закон України від 05.09.2017 p. № 2145-19. URL: http://zakon3.rada.gov. ua/laws/show/2145-19.

12. Програма вивчення навчальної дисципліни «Соціально-педагогічна робота в закладах освіти» 
для студентів напряму підготовки 6.010106 «Соціальна педагогіка». Львів. 2016. 13 с. URL: https:// is.gd/aEYYIT.

13. Програма курсу «Технології соціально-педагогічної діяльності» для студентів напряму підготовки «Соціальна педагогіка». Кропивницький. 2015. URL: https://is.gd/9FzpLM.

14. Робоча програма навчальної дисципліни «Основи соціалізації особистості» для студентів напряму підготовки 6.010106 «Соціальна педагогіка». Луцьк. 2013. 11 с. URL: https://eenu.edu.ua/ sites/default/files/Files/robocha programa osnovi socializaciyi_osobistosti.pdf.

15. Робоча програма навчальної дисципліни «Соціально-педагогічна робота в закладах освіти» для студентів напряму підготовки 6.010106 «Соціальна педагогіка». Київ. 2016. 51 с. URL: http://il.kubg. edu.ua/images/RP_KSPSR/20152016/A_Popova_ SPRZO_SP_IL.pdf

16. Робоча програма навчальної дисципліни «Соціально-педагогічна робота у закладах освіти» для студентів спеціальності 7.01010601 «Соціальна педагогіка». Житомир. 2014. 19 c. URL: https://is.gd/ GOUUbY.
17. Робоча програма навчальної дисципліни «Технології соціально-педагогічної діяльності» для студентів напряму підготовки 6.010106 «Соціальна педагогіка». Київ. 2015. 92 c. URL: https://is.gd/y99V8J.

18. Сучасні технології збереження здоров'я учнів: кращий досвід (електронні дані) / авт. кол.; уклад. А.Г. Обухівська, І.І. Цушко. Київ : Український НМЦ практичної психології і соціальної роботи, 2015. $221 \mathrm{c}$

19. Терпелюк В.В. Соціально-педагогічна робота в закладах освіти: робоча програма для студентів напряму підготовки 6.010106 Соціальна педагогіка. Кременець, 2016. 20 с.

20. Технології соціально-педагогічної роботи: програма навчальної дисципліни / уклад. Р.Х. Вайнола. Київ : Київський університет імені Бориса Грінченка. 2012. 33 с.

21. Токарева Н.М. Сучасний підліток у системі психолого-педагогічного супроводу : монограсрія / Н.М. Токарева, А.В. Шамне, Н.М. Макаренко. Кривий Ріг, 2014. 312 с.

22. Фіцула М.М. Педагогіка : посібник. Київ : Академвидав, 2003. 528 с. 